\title{
Trophic coupling of rotifers, microflagellates, and bacteria during fall months in the Rhode River Estuary
}

\author{
John R. Dolan, Charles L. Gallegos \\ Smithsonian Environmental Research Center, PO Box 28, Edgewater, Maryland 21037-0028, USA
}

\begin{abstract}
Field patterns and experimental results suggested that rotifers, by grazing heterotrophic microflagellates, may have exerted an indirect effect on bacterioplankton concentration. A rotifer population (Synchaeta sp.) oscillated out of phase with total microflagellate (autotrophic and heterotrophic) concentration, and heterotrophic microflagellate concentrations oscillated out of phase with bacterial abundance in the Rhode River (USA). Similar patterns were found in a time-course study of isolated water samples. Grazing experiments indicate that the rotifer cleared the water of both heterotrophic and autotrophic microflagellates at 10 to $16 \mu \mathrm{h} \mathrm{h}^{-1}$ rotifer $^{-1}$ The apparent predator-prey relationships of rotifer-microflagellate and heterotrophic microflagellate-bacteria were formally defined in a model of a rotifer-microflagellate-bacteria food web using grazing and growth rates from field patterns and experiments. The model successfully mimicked field abundance patterns supporting the hypothesis that rotifers, microflagellates and bacteria form a highly interactive system in which rotifers exert an indirect effect on bacterioplankton.
\end{abstract}

\section{INTRODUCTION}

The 'microbial loop' concept (Azam et al. 1983) was put forward, in part, as an account of the fate of bacterial carbon in plankton ecosystem. In this loop, dissolved organic matter is packaged by bacteria which are consumed by heterotrophic microflagellates and ciliates. If bacteriovores are eaten by metazoan zooplankton the loop can function as a pathway for bacterial carbon to enter the 'traditional' food chain of zooplankton-nekton (Ducklow et al. 1986). The importance of carbon flux through bacteria continues to be demonstrated for a variety of aquatic environments, from estuaries (Coffin \& Sharp 1987) to the open ocean (Hopkinson et al. 1989, Malone \& Ducklow 1990). Likewise, recent work continues to confirm the hypothesized role of microflagellates and small ciliates as primary bacteriovores (Sherr et al. 1989) and shows that protists can control abundance, production and size structure of the bacterial community (Chrzanowski \& Simek 1990, Gonzalez et al. 1990, Kuuppo-Leinikki 1990). What remains unsettled is the relationship of the microbial loop to the metazoan zooplankton-nekton food chain.
A 'link vs sink' controversy, as it has come to be known, has revolved primarily around questions as to how much carbon is left for metazoan zooplankton after bacterial and protistan respiration (Ducklow et al. 1986 , Sherr et al. 1987). However, the possible role of metazoan zooplankton in structuring the microbial loop, i.e. regulating the abundance and/or composition of bacteriovores and thereby indirectly affecting the bacterioplankton, has, to our knowledge, not been critically examined. Indeed, this is surprising because predation has long been recognized as able to shape both the species compositions and densities of lower trophic levels in freshwater planktonic and marine benthic communities (Elser \& Carpenter 1988).

This report deals with structure and function of the microbial loop in the Rhode River, a eutrophic subestuary of the Chesapeake Bay, USA. We present evidence that during fall months, when rotifers are abundant, a rotifer-microflagellate-bacteria food web develops in which heterotrophic microflagellate abundance is likely regulated by both bacterial concentration and rotifer grazing pressure. Periods of high bacterial concentration represent the indirect result of rotifers grazing heterotrophic microflagellates. 


\section{METHODS AND MATERIALS}

Field sample collection and processing. Samples were gathered during daylight hours off the Smithsonian dock on the Rhode River, Maryland (USA), at 1 to $4 \mathrm{~d}$ intervals from late October to mid-December at slack tide by immersing a $10 \mathrm{l}$ jug ca $10 \mathrm{~cm}$ below the surface. Aliquots $(20 \mathrm{ml})$ for bacterial, microflagellate and ciliate counts were fixed with EM grade glutaraldehyde (final concentration $1 \%$ ). A 21 subsample was concentrated over a $20 \mu \mathrm{m}$ Nitex screen to $20 \mathrm{ml}$ and fixed with glutaraldehyde for metazoan zooplankton counts. Microflagellates and bacteria were enumerated following the protocols of Hass (1982) and Porter \& Feig (1980). Ciliates were counted in whole water samples, rotifers and other metazoan plankters in the concentrates, using an inverted microscope. Replicate samples $(\mathrm{n}=5)$ yielded a sample error estimate (CV) of 10 to $20 \%$, with the higher amount associated with estimates of rotifer abundance.

Temperature, salinity and in vivo fluorescence data were gathered from an automated sampling station, previously described (Cory \& Dresler 1981). As part of a separate, long-term phytoplankton study, samples for chlorophyll analysis were taken at approximately weekly intervals and processed following the protocol outlined in Gallegos (1989).

Rotifer grazing experiments. Experiments were run in late October and early November using the experimental design and rate calculation methods of Frost (1972). Eight $20 \mathrm{ml}$ polycarbonate scintillation vials were filled with rotifer-free $(20 \mu \mathrm{m}$ screened) water. Twenty rotifers were added to 3 or 4 containers, the rest serving as controls, half of which were preserved immediately for time=zero estimates of flagellate abundance. The remaining containers were incubated for $24 \mathrm{~h}$ in an open, outdoor, bath which was flushed with water pumped from near the sample site. The flushing action in the water bath kept the vials circulating constantly; there was no obvious settling of material in the vials. Samples were fixed and processed for microflagellate counts as described above.

Time course study. A time-course study of large, size-fractionated water samples was run in midNovember. Abundance trends were examined to confirm the patterns seen in the estuary seperate from any benthic influence, and to investigate the effects of reduced and increased rotifer concentrations. A $200 \mathrm{l}$ container was filled with dock water using the method employed for field sampling. This single water sample was used to sequentially fill 3 aquaria (ca 70 I). The first tank was filled with whole (untreated) water. A second tank was filled with water siphoned through a $20 \mu \mathrm{m}$ screen, yielding water which was nominally rotiferfree. The concentrate retained by the $20 \mu \mathrm{m}$ screen was added to the third tank which now contained an elevated concentration of rotifers. To maintain in situ temperature and light conditions, the 3 tanks were placed in a deep, outdoor water table in which water pumped from near the sample site constantly circulated. After gentle stirring, samples (2 1) were removed daily for $6 \mathrm{~d}$ and processed for estimates of bacteria, microflagellate, ciliate and rotifer abundance

Grazing rates of heterotrophic microflagellates on bacteria were calculated to provide a clearance rate estimate for a computer model of a rotifer-microflagellate food web (see 'Discussion'). Grazing parameters, based on changes in the abundances of bacteria and heterotrophic microflagellates in the tank without rotifers, were calculated over 4 time periods using the equations of Heinbokel (1978). Bacterial growth in the absence of grazing was conservatively estimated as the average rate during 2 periods of growth observed in the tank without rotifers but in the presence of heterotrophic microflagellates.

\section{RESULTS}

\section{Abundance trends in the Rhode River}

The metazoan zooplankton (Table 1) were dominated numerically by a small (ca $130 \mu \mathrm{m})$ Synchaeta sp. (sp. $1=S$. cecilia?) rotifer. The density of $\mathrm{sp} .1$ varied

Table 1. Summary of organism concentrations and temporal presence based on samples taken from late October to midDecember 1990

\begin{tabular}{|c|c|c|}
\hline Organism & $\begin{array}{c}\text { Average conc. } \\
\text { (SD) }\end{array}$ & $\begin{array}{l}\% \text { Dates } \\
\text { present }\end{array}$ \\
\hline \multicolumn{3}{|c|}{ Metazoan zooplankton $\mathrm{l}^{-1}$} \\
\hline Synchaeta sp. 1 & $671(1,142)$ & 94 \\
\hline Synchaeta sp. 2 & $51(64)$ & 56 \\
\hline Polychaete larvae & $13(21)$ & 97 \\
\hline Copepod nauplii & $5(4)$ & 97 \\
\hline Veliger larvae & $5(6)$ & 75 \\
\hline Barnacle nauplij. & $2(1)$ & 59 \\
\hline Copepods & $1(2)$ & 28 \\
\hline \multicolumn{3}{|l|}{ Ciliates $\mathrm{ml}^{-1}$} \\
\hline Balanion sp & $39(105.6)$ & 74 \\
\hline Mesodinium pulex & $12(13.6)$ & 71 \\
\hline Myrionecta rubrum & $7(12.2)$ & 52 \\
\hline Strombidium sp. 1 & $5(8.4)$ & 48 \\
\hline Mesodinium sp. & $4(8.6)$ & 52 \\
\hline Cyclidium sp. & $4(5.5)$ & 52 \\
\hline Strombidium sp. 2 & $3(6.2)$ & 32 \\
\hline \multicolumn{3}{|c|}{ Microflagellates $\times 10^{3} \mathrm{ml}^{-1}$} \\
\hline Autotrophic & $38(14.4)$ & 100 \\
\hline Heterotrophic & $8(3.3)$ & 100 \\
\hline Bacteria $\times 10^{6} \mathrm{ml}^{-1}$ & $1.4(0.757)$ & 100 \\
\hline
\end{tabular}




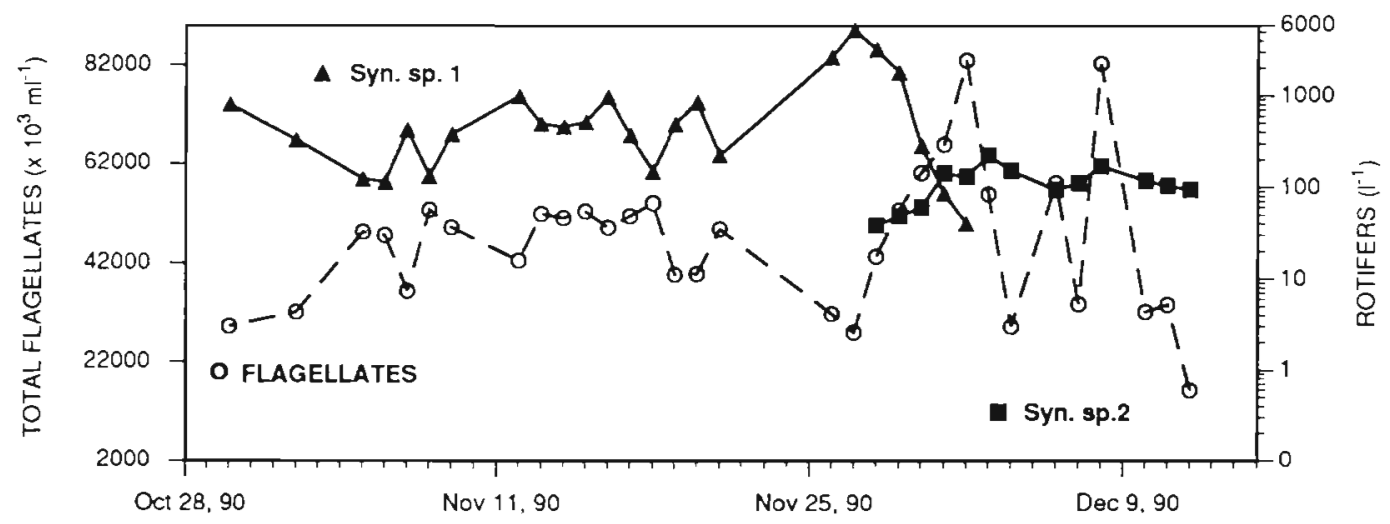

Fig. 1. Temporal changes in abundances of microflagellates (autotrophic and heterotrophic) and rotifers (Synchaeta species 1, Syn. sp. 1 and species 2, Syn sp. 2) in the Rhode River estuary

widely (100 to $5000 \mathrm{l}^{-1}$ ) and inversely with total microflagellate concentration (Fig. 1). The 2 populations oscillated out of phase with a period of about 4 to $8 \mathrm{~d}$ Synchaeta sp. 1 appeared to grow exponentially when total flagellate concentrations exceeded $\approx 50000 \mathrm{ml}^{-1}$ and to decline abruptly when flagellates fell below this value. Flagellate concentration did not appear to decline until rotifers reached a density of ca $1000 \mathrm{l}^{-1}$.

During the first week of December, which followed a drop in the water temperature to below $7^{\circ} \mathrm{C}$ (Fig. 4), Synchaeta sp. 1 abruptly disappeared and a much larger $(\sim 300 \mu \mathrm{m})$ Synchaeta $\mathrm{sp}$. (species $2,=S$. baltica?) increased in abundance (Fig. 1). The flagellate population fluctuated widely $(\approx 30000$ to 80000 cells $\mathrm{ml}^{-1}$ ) with only minor variations in the abundance $(94$ to $2241^{-1}$ ) of the large rotifer.

The heterotrophic microflagellate component of total microflagellates formed a small $(<1 / 4)$ proportion of total flagellates (Table 1). Both bacteria and heterotrophic microflagellates oscillated with a period of 4 to $8 \mathrm{~d}$ but the relationship between the 2 populations was unclear. While high rates of bacterial decline were associated with high stocks of heterotrophic micro- flagellates (see Fig. 2: Nov 12 to 15,17 to 19) and low concentrations of bacteria (below $1 \times 10^{6} \mathrm{ml}^{-1}$ ) immediately preceeded declines in heterotrophic microflagellates (see Fig. 2: Nov 7, 14, 18, 21), high concentrations of bacteria (Nov 2 to 5,9 to 12,27 , Dec 2) were not associated with, or found to immediately precede, large standing stocks of heterotrophic microflagellates. Peak bacterial numbers (Nov 9 to 14, 26 to 30) were associated with high concentrations of rotifers (cf. Figs. $1 \& 2$ : Nov 9 to 12,26 to 30 ). Low heterotrophic microflagellate numbers occurred with both low stocks of bacteria and high concentrations of rotifers (Nov 16, 20,26 to 30 ).

Ciliate abundances (Fig. 3) generally ranged between 10 and 100 cells $\mathrm{ml}^{-1}$. The ciliate community was dominated by a small (30 $\mu \mathrm{m}$ dia.) Balanion sp.; other common forms included raptorially-feeding Mesodinium spp, and the phototrophic Myrionecta rubrum (Table 1). Bacteriovores, such as Cyclidium, were a minor component of the assemblage. Ciliates did not show any clear relationship with the flagellate or bacterial populations. Although food vacuole contents of most cells were unidentifiable, many ciliates

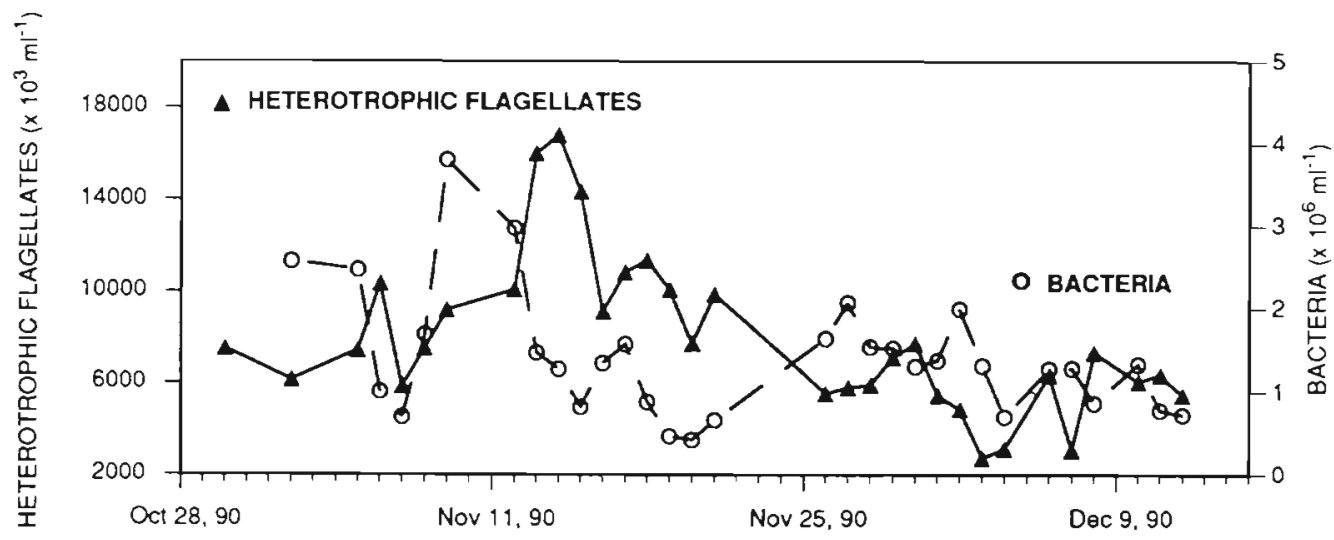

Fig. 2. Temporal changes in abundances of heterotrophic microflagellates and bacteria in the Rhode River estuary 


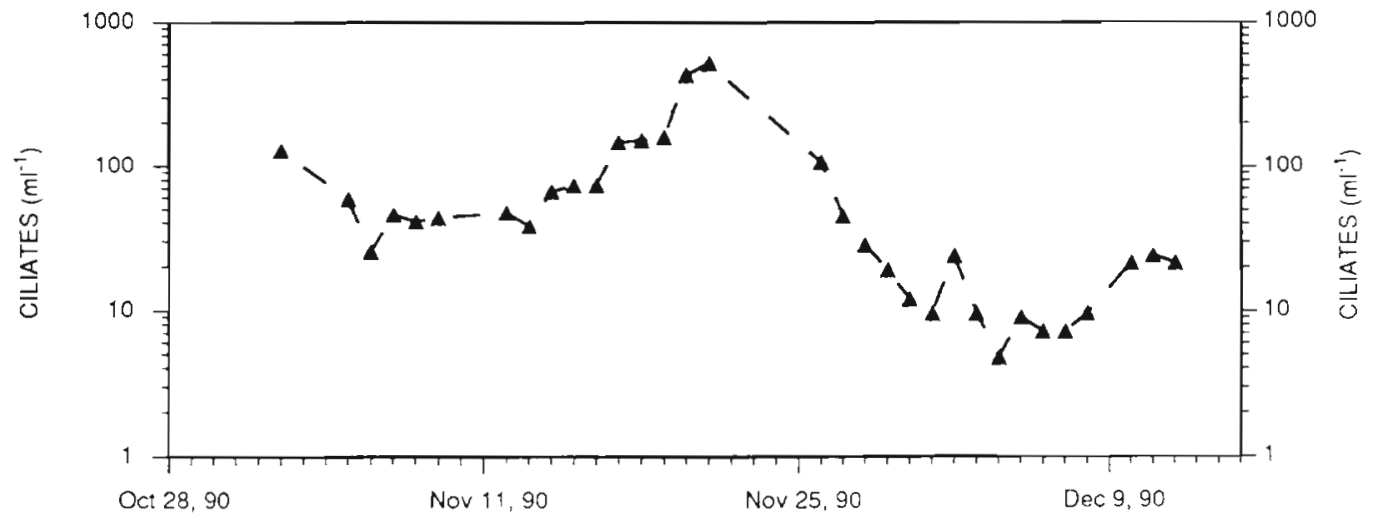

Fig. 3. Temporal changes in abundances of ciliates in the Rhode River Estuary

(Balanion sp.) appeared to contain the remains of dinoflagellate prey. The relatively low abundance of 'typical' filter-feeding forms known to ingest microflagellates such as oligotrichs and tintinnids may explain the lack of a relationship between flagellates and ciliates.

Temperature declined erratically through the study period from ca $16^{\circ} \mathrm{C}$ to ca $7^{\circ} \mathrm{C}$. Both temperature and salinity were variable (Fig.4) but none of the populations varied with either parameter. Likewise, no obvious relationships were seen with chlorophyll concentration, as indicated by fluorescence (Fig. 5). Although no attempt was made to partition the chlorophyll crop into size-fractions, from casual observations it was apparent that chlorophyll peaks were associated with dense populations of the dinoflagellate Prorocentrum minimum.

Linear correlation analysis between population densities and water quality parameters (salinity, temperature, chlorophyll) revealed no significant relationship between any of the populations and water quality measures, untransformed or log transformed, with or without time lags of 1 to $4 \mathrm{~d}$. Similar analyses of all possible pairs of populations revealed no significant correlations.
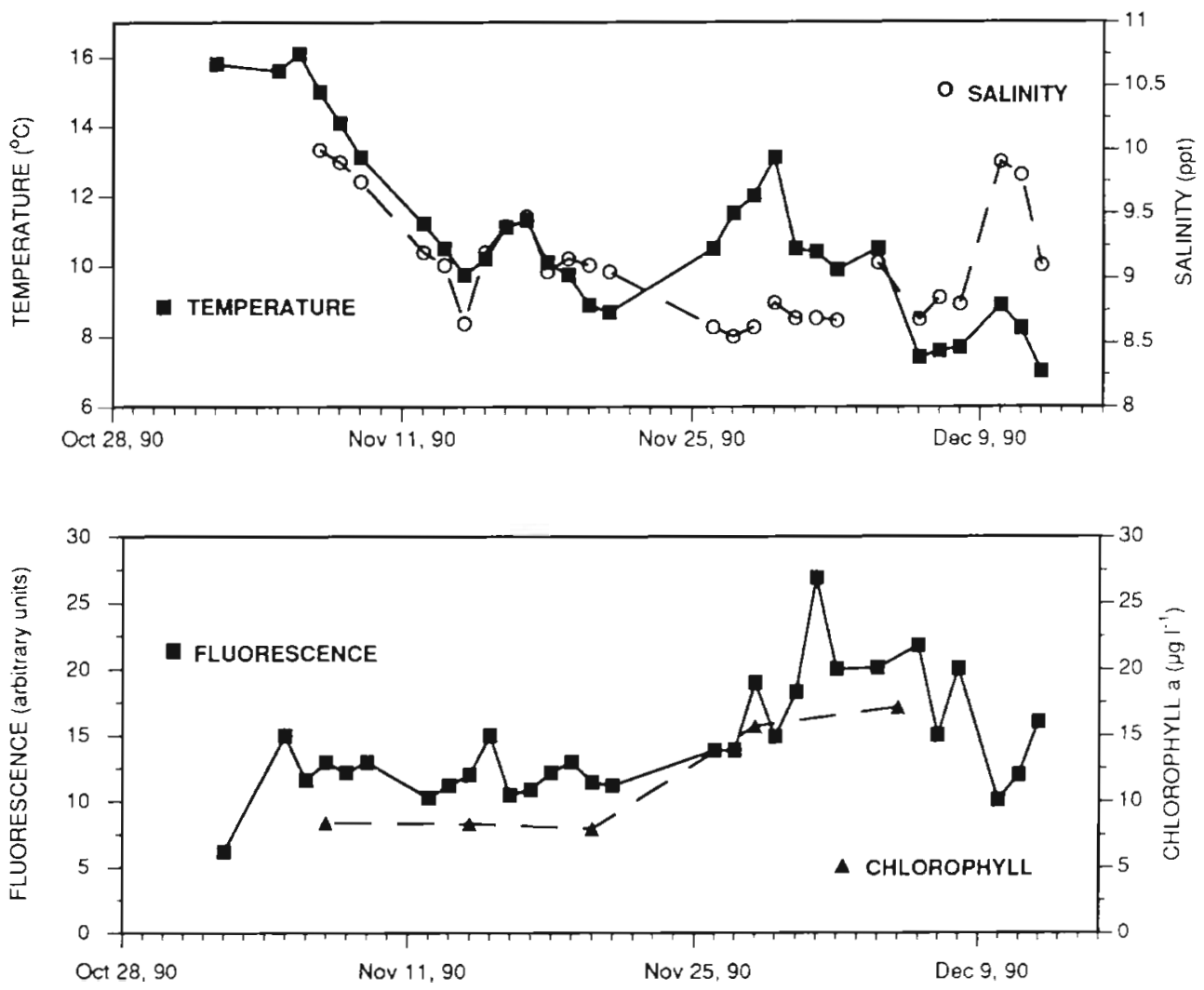

Fig. 4. Temporal changes in temperature and salinity of Rhode River water
Fig. 5. Temporal changes of in vivo flourescence values and chlorophyll a concentrations in Rhode River waters 


\section{Grazing experiments}

Synchaeta sp. 1 cleared flagellates at rates ranging from 8.7 to $17.8 \mu$ rotifer ${ }^{-1} \mathrm{~h}^{-1}$. Higher rates $(x=16.2$, range $=14.6$ to $17.8 \mu \mathrm{l} \mathrm{h}^{-1}$ ) were observed when the average concentration of flagellates was ca $20000 \mathrm{ml}^{-1}$. In the second experiment the average concentration of flagellates was ca 50000 flagellates $\mathrm{ml}^{-1}$ and the average clearance was ca $10 \mu$ rotifer $^{-1} \mathrm{~h}^{-1}$ (range $=8.7$ to 11.9 ) . In both experiments there was no significant difference between the clearance rates estimated on autotrophic and heterotrophic microflagellates (Table 2).

\section{Time course study}

The time course study of size-fractionated water samples confirmed the relationships seen in the field patterns. In the tank without rotifers (Fig.6a), total flagellates slowly increased and ciliates grew exponentially from ca 50 to $400 \mathrm{ml}^{-1}$. Unlike total flagellates, heterotrophic microflagellates oscillated between 12000 and $22000 \mathrm{ml}^{-1}$, and bacteria varied between ca 1 and $3 \times 10^{6} \mathrm{ml}^{-1}$. Changes in heterotrophic microflagellate concentrations lagged behind bacteria by about 1 sampling period.

Grazing rates of heterotrophic microflagellates, calculated over the time periods which began with at least $1.5 \times 10^{6}$ bacteria $\mathrm{ml}^{-1}$, are presented in Table 3 . We estimated bacterial growth as $0.034 \mathrm{~h}^{-1}$, which represents the average of 2 periods of population growth at rates of 0.020 and $0.047 \mathrm{~h}^{-1}$. Using this average, we estimate that heterotrophic microflagellates cleared an average of $3.56 \mathrm{nl}$ flagellate ${ }^{-1} \mathrm{~h}^{-1}(\mathrm{SD}=1.052)$ and ingested an average of $6.8(\mathrm{SD}=0.977)$ bacteria flagellate $^{-1} \mathrm{~h}^{-1}$

In the tank filled with unaltered water (Fig. 6b, in situ rotifer concentration), total flagellate numbers first increased slightly, then declined as rotifer numbers increased from $\sim 500$ to $2000 \mathrm{l}^{-1}$. Over the last sampling period, a decline in rotifer numbers coincided with an increase in flagellate concentrations. As in the tank with rotifers removed, ciliates grew exponentially (data not shown), increasing from 100 to $350 \mathrm{ml}^{-1}$ and then declining slightly over the last sampling period. Heterotrophic microflagellate populations largely paralleled the changes in total flagellates, in contrast to the pattern seen in the tank without rotifers. Concentrations at first increased slightly and then declined and were lower in the last half of the experiment when rotifers exceeded $1000 \mathrm{l}^{-1}$. Bacterial concentrations declined over the first 3 sampling periods and then remained stable at ca $1.2 \times 10^{6} \mathrm{ml}^{-1}$.

In the tank with increased rotifer concentrations (Fig. 6c), total flagellates oscillated between 38000 and $55000 \mathrm{ml}^{-1}$ while rotifers varied from ca 1000 to $3000 \mathrm{l}^{-1}$. Ciliates increased in concentration steadily from $\sim 100$ to $350 \mathrm{ml}^{-1}$ and then decreased slightly (data not shown), similar to the tank with in situ rotifer concentration.

Temporal changes in the numbers of heterotrophic microflagellates roughly corresponded with the pattern of total microflagellates, similar to trends seen in the tank with in situ rotifer concentrations. Bacterioplankton concentrations also oscillated, and almost exactly paralleled changes in rotifer concentrations with corresponding population peaks.

Few metazoan zooplankters other than rotifers were present in the tanks containing unaltered water or an increased rotifer concentration. Abundances of polychaete larvae and barnacle nauplii were similar to the average field concentrations, 5 to $10 \mathrm{l}^{-1}$.

\section{DISCUSSION}

Cascading trophic interactions are well known from freshwater plankton communities and are epitomized by changes in grazer-phytoplankton assemblages which follow changes in the composition of the fish community (McQueen et al. 1989). Typically, planktivorous fish regulate not only the abundance but the composition of the herbivorous zooplankton, which in turn determines the abundance and composition of the

Table 2. Results of rotifer grazing experiments. Number of replicates $(\mathrm{N})$, prey concentrations $\left(\times 10^{3} \mathrm{ml}^{-1}\right)$ of heterotrophic (Hflag), autotrophic (Aflag) and total microflagellates (Tflag). Numbers in parentheses are standard deviations

\begin{tabular}{|c|c|c|c|c|c|c|}
\hline Date & $\begin{array}{c}\text { Controls } \\
\mathrm{N}\end{array}$ & $\begin{array}{c}\text { Grazer } \\
\mathrm{N}\end{array}$ & $\begin{array}{l}\text { Prey } \\
\text { group }\end{array}$ & $\begin{array}{l}\text { Prey conc. } \\
\quad\langle\mathrm{C}\rangle\end{array}$ & $\begin{array}{l}\text { Filtration } \\
\mu l \mathrm{~h}^{-1}(\mathrm{SD})\end{array}$ & $\begin{array}{c}\text { Ingestion } \\
\text { cells } \mathrm{h}^{-1}(\mathrm{SD})\end{array}$ \\
\hline Oct 30 & 2 & 2 & $\begin{array}{l}\text { Tflag } \\
\text { Aflag } \\
\text { Hflag }\end{array}$ & $\begin{array}{c}23382(1218) \\
16846(474) \\
5519(750)\end{array}$ & $\begin{array}{l}16.2(2.3) \\
16.5(4.2) \\
15.8(3.2)\end{array}$ & $\begin{array}{c}380(94.6) \\
279(78.4) \\
86(6.0)\end{array}$ \\
\hline Nov 7 & 2 & 3 & $\begin{array}{l}\text { Tflag } \\
\text { Aflag } \\
\text { Hflag }\end{array}$ & $\begin{array}{r}54162(533) \\
47116(462) \\
7041(420)\end{array}$ & $\begin{array}{r}10.2(1.6) \\
8.4(1.1) \\
22.2(7.9)\end{array}$ & $\begin{array}{l}556(85.3) \\
397(49.8) \\
154(48.5)\end{array}$ \\
\hline
\end{tabular}




\section{a. ROTIFERS REMOVED}
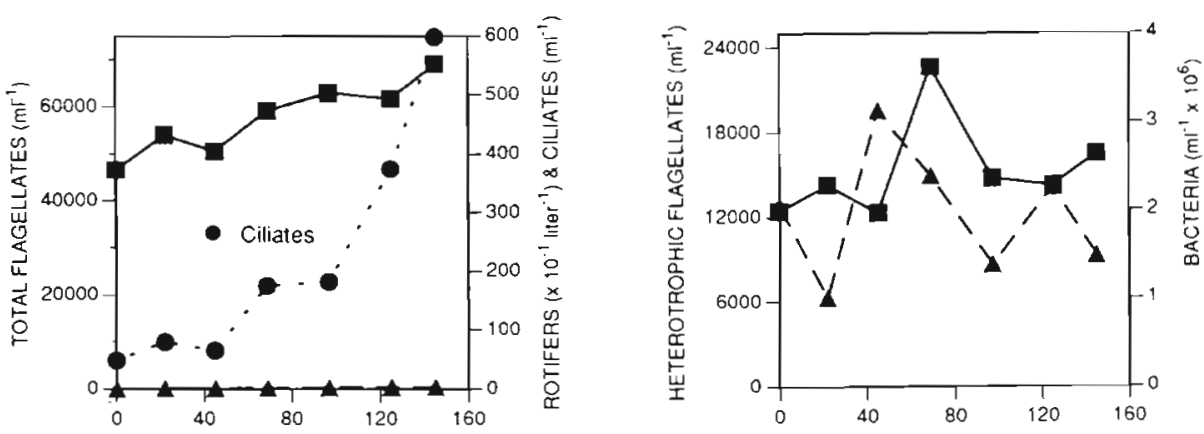

b. IN SITU ROTIFER CONC.
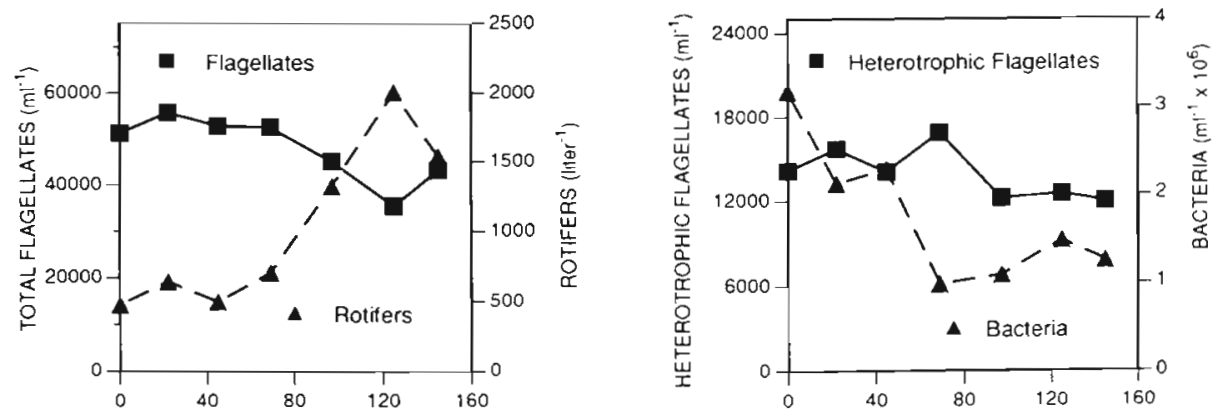

\section{C. $2 X$ IN SITU ROTIFER CONC.}
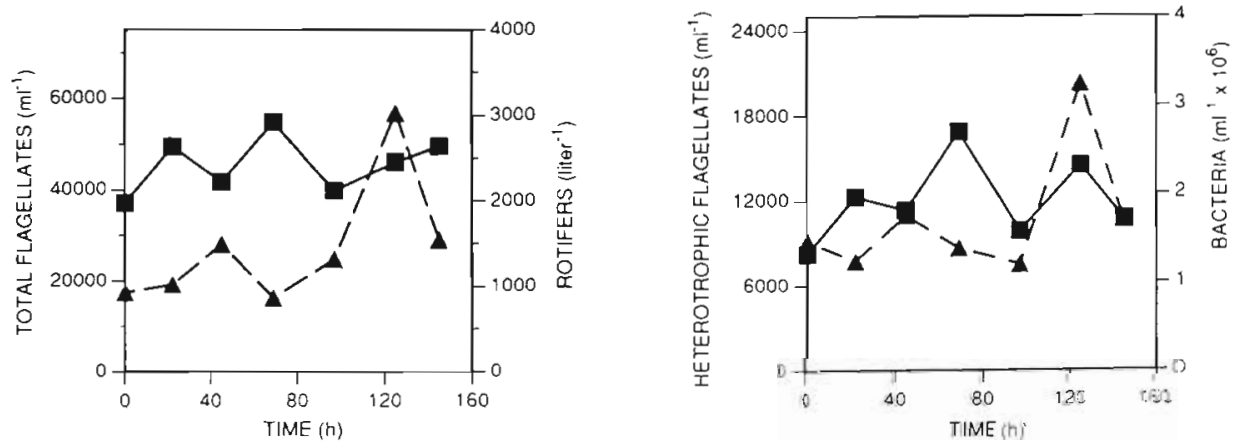

Fig. 6. Results of time course study of size-fractionated water. Temporal changes in total microflagellates, rotifers (Synchaeta species 1), heterotrophic microflagellates and bacteria in water with (a) rotifers removed, (b) in situ rotifer concentrations and (c) increased rotifer concentrations. Ciliate concentrations are shown only for water with rotifers removed, similar trends occurred in the remaining treatments (see results for details\}

Table 3. Estimates of heterotrophic microflagellate grazing rates based on changes in population densities in $20 \mu \mathrm{m}$ screened water followed over 6 d (Fig. 6). Average concentrations $\langle\mathrm{C}\rangle$ in numbers $\mathrm{ml}^{-1}$

\begin{tabular}{|ccccc|}
\hline $\begin{array}{c}\text { Time period } \\
\mathrm{T}_{0}-\mathrm{T}_{\mathrm{x}}\end{array}$ & $\begin{array}{c}\text { HFLAG } \\
\langle\mathrm{C}\rangle\end{array}$ & $\begin{array}{c}\text { BAC } \\
\langle\mathrm{C}\rangle\end{array}$ & $\begin{array}{c}\text { Filtration } \\
\mathrm{nl} \mathrm{h}^{-1}\end{array}$ & $\begin{array}{c}\text { Ingestion } \\
\text { cells }^{-1}\end{array}$ \\
\hline $0-22$ & 13330 & 1466000 & 4.99 & 7.3 \\
$46-69$ & 16940 & 2733000 & 2.65 & 7.3 \\
$69-97$ & 18390 & 1838000 & 2.90 & 5.3 \\
$121-145$ & 15330 & 1975000 & 3.70 & 7.3 \\
\hline
\end{tabular}

phytoplankton; thus the fish exert an indirect, or cascading effect on a lower trophic level, i.e. the phytoplankton (Kerfoot 1987). In the Rhode River estuary, rotifers appear to exert a variable, indirect effect on bacterioplankton concentration.

Heterotrophic microflagellates have been shown repeatedly to control the abundance of bacteria in a large variety of systems (reviewed in Capriulo et al. 1991) and probably do so in the Rhode River where they are relatively abundant compared to the standing stock of bacteria. In turn, the rotifer population, while not exerting a constant control on the microflagellate populations, does appear at times to reduce the standing stock of microflagellates. High bacterial numbers and low heterotrophic microflagellate stocks corresponded with high rotifer stocks (Figs. $1 \& 2$ ). Rotifers probably exert a varying indirect effect on the abundance of bacteria by reducing microflagellate grazing 
pressure on bacterioplankton. This type of an indirect effect has been termed a trophic linkage indirect effect' (Miller \& Kerfoot 1987).

The concentrations of the microbial loop populations observed here are similar to those reported by others. Bacterial concentrations corresponded with previous reports of autumn abundances for the Rhode River (Rublee et al. 1984). Microflagellate numbers, although higher than those reported for the mainstem of the Chesapeake Bay, were well within the range of concentrations reported for meso- and polyhaline estuarine waters (Dolan \& Coats 1990). Rotifer population densities, which ranged from $10^{2}$ to $10^{3} 1^{-1}$, may be typical of estuarine waters. For example, peak concentrations of several thousand rotifers per liter have been recorded for the estuarine portion of the Potomac River (Heinbokel et al. 1988), and Perch Pond, Massachusetts (Egloff 1988). In the mainstem of the Chesapeake Bay, rotifers display a peak density of ca $500 \mathrm{l}^{-1}$ in November, based on samples integrated over the entire water column and averaged from several stations (Brownlee \& Jacobs 1987).

Similarly, the relationships between the different populations have been reported before. Bacteriamicroflagellate coupling apparent from the field data and confirmed in the tank experiment is a relatively well-known phenomenon (Kuuppo-Leinikki 1990). Correlations between rotifers and microflagellates in freshwater systems have been noted (Cushing 1976), and laboratory studies have consistently shown that rotifers, especially Synchaeta spp., grow best on a diet of small flagellates, such as cryptomonads (Pourriot 1977, Egloff 1988) which are one of the dominant phytoplankters in the Rhode River (Gallegos 1989).

Minimal food concentrations for the 2 predators in the system which were suggested by the field patterns and the tank experiment corresponded with previous studies. Fenchel (1986) found that a minimal concentration of 0.5 to $1.0 \times 10^{6}$ bacteria $\mathrm{ml}^{-1}$ was needed to support logarithmic growth of heterotrophic microflagellates. However, given the relatively large standing stocks of heterotrophic microflagellates and considering that they may consume autotrophic flagellates (reviewed in Grover 1990 and Sherr et al. 1991), it is possible that bacteriovory by heterotrophic microflagellates was supplemented with herbivory. The apparent minimal food concentration for rotifer growth fell well within the range reported for freshwater rotifers of a size similar to Synchaeta spp. 1 (Stemberger \& Gilbert 1985, 1987).

The grazing rates reported here also agree with previous studies. Results of the experiments with the small Synchaeta sp. (species 1) and natural flagellate populations yielded clearance rate estimates within the range reported for other Synchaeta species (Gilbert \& Bogdan
1984) and were very similar to those found in studies with the similar-sized Synchaeta cecilia, i.e. 2 to $18 \mu \mathrm{l}$ rotifer $\mathrm{h}^{-1}$ (Egloff 1988). Heterotrophic microflagellates were estimated to clear bacteria at ca 3.5 nl flagellate ${ }^{-1}$ $\mathrm{h}^{-1}$. Grazing rate estimates for heterotrophic microflagellates range widely but are generally found to be between 2 and $4 \mathrm{nl}$ flagellate $\mathrm{h}^{-1}$ for field populations (Capriulo et al. 1991).

Predator-prey relationships inferred from field data are at best tentative (Davis et al 1985) because organisms are rarely controlled exclusively by a single consumer. With regard to bacteria for example, heterotrophic microflagellates are usually the dominant bacteriovore, but viruses (Borsheim et al. 1990) and some chloroplast-containing microflagellates (Sanders 1991) also exploit bacteria. The second most abundant metazoan encountered, polychaete larvae, although found in very low numbers relative to rotifers (Table 1 ), consumes phytoplankton at rates approximately equal to those reported here for Synchaeta sp. 1 (Sellner et al. 1987). It is also concievable that some form of benthicpelagic coupling could have played a role in the field patterns observed. However, in the Rhode River infaunal invertebrates, epibenthic fish and epibenthic crabs are all at an annual low in late fall-early winter (Hines et al. 1987). Furthermore, in the tank experiments water was removed from any benthic influence and patterns of population abundances were similar to those seen in field samples.

Given the apparent reasonable nature of the rotifermicroflagellate and microflagellate-bacteria relationships we constructed a computer simulation model of a food web to confirm that the 2 predator-prey systems could interact and possible produce abundance patterns similar to those seen in the field populations.

A relatively simple 3-level predator-prey system was modeled using population growth rates, death rates and carrying capacities estimated from field data; rotifer clearance rates from the grazing experiments and heterotrophic microflagellate grazing rates from the time-course study (Table 4). It should be emphasized the rates employed were 'apparent', e.g. carrying capacities as maximum observed population densities, population growth rates as maximum observed regardless of possible predator abundance.

The model consisted of 4 components: rotifers, autotrophic microflagellates, heterotrophic microflagellates, and bacteria. We modeled the growth of all 4 populations using the logistic equation by setting the maximal growth rate as the highest net growth rate observed in the field data, and the carrying capacity as the maximum observed concentration. Exponential death rates were imposed on rotifers and heterotrophic microflagellates when prey densities (total flagellates and bacteria, respectively) fell below the 
Table 4. Parameters used in the model rotifer-microflagellate-bacteria food web. FD: field data. See 'Discussion' for details

\begin{tabular}{|c|c|c|}
\hline Rate & Value & Source \\
\hline \multicolumn{3}{|l|}{ Rotifers } \\
\hline Growth $\left(d^{-1}\right)$ & 1.32 & FD: Nov 16 to 11 , Fig. 1 \\
\hline Minimum prey conc. $\left(\mathrm{ml}^{-1}\right)$ & 50000 & FD: Fig. 1 \\
\hline Death $\left(\mathrm{d}^{-1}\right)$ & 1.16 & FD:Nov 7 to 8 , Fig. 1 \\
\hline Carrying capacity $\left(\mathrm{ml}^{-1}\right)$ & 6.00 & FD:Nov 27 , Fig 1 \\
\hline Clearance $\left(\mathrm{ml} \mathrm{d}^{-1}\right)$ at conc. $>20000 \mathrm{ml}^{-1}$ & 0.24 & Grazing experiment \\
\hline Clearance $\left(\mathrm{ml} \mathrm{d}^{-1}\right)$ at conc $<20000 \mathrm{ml}^{-1}$ & 0.38 & Grazing experiment \\
\hline \multicolumn{3}{|l|}{ Heterotrophic microflagellates } \\
\hline Growth $\left(\mathrm{d}^{-1}\right)$ & 0.87 & FD:Dec 7 to 8 , Fig. 2 \\
\hline Minimum prey conc $\left(\mathrm{ml}^{-1}\right)$ & 1000000 & FD: Fig. 2 \\
\hline Death $\left(d^{-1}\right)$ & 0.57 & FD Nov 6 to 7 , Fig. 2 \\
\hline Clearance $\left(\mathrm{ml} \mathrm{d}^{-1}\right)$ & 0.000085 & Time-course experiment \\
\hline Carrying capacity $\left(\mathrm{mI}^{-1}\right)$ & 24000 & Time-course experiment \\
\hline \multicolumn{3}{|l|}{ Autotrophic microflagellates } \\
\hline Growth $\left(\mathrm{d}^{-1}\right)$ & 1.69 & FD: Nov 27 to 28, DNS \\
\hline Carrying capacity $\left(\mathrm{ml}^{-1}\right)$ & 80000 & FD Dec 2, DNS \\
\hline \multicolumn{3}{|l|}{ Bacteria } \\
\hline Growth $\left(d^{-1}\right)$ & 0.81 & FD:Nov 8 to 9. Fig. 2 \\
\hline Carrying capacity $\left(\mathrm{ml}^{-1}\right)$ & 4000000 & FD:Nov 9, Fig. 2 \\
\hline
\end{tabular}

minimal values at which positive predator growth was observed in the field data. Rotifer growth rate was linked to the previous day's prey concentration as the egg development time for Synchaeta spp. is ca 24 h at $10^{\circ} \mathrm{C}$ (Heinbokel et al. 1988). Bacteria were subjected to removal by heterotrophic microflagellates using the average clearance rate estimated from the time-course experiment. Both flagellate compartments were subjected to removal by rotifers using a clearance rate rotifer ${ }^{-1} \mathrm{~d}^{-1}$ equivalent to $16 \mu \mathrm{h} \mathrm{h}^{-1}$ at prey concentrations below $20000 \mathrm{ml}^{-1}$ and $10 \mu \mathrm{h}^{-1}$ at higher prey abundances.

The model produced temporal patterns that were remarkably close to those seen in the field data (Fig. 7). At steady state, the population densities oscillated with amplitudes and periods similar to those of natural populations. In the field rotifers oscillated between ca 100 and $60001^{-1}$ compared to $\sim 70$ to $40001^{-1}$ for the model population. Total flagellates in the field varied from ca 27000 and $80000 \mathrm{ml}^{-1}$ compared to 18000 to $90000 \mathrm{ml}^{-1}$ for model populations. Heterotrophic microflagellates ranged from ca 3000 to $17000 \mathrm{ml}^{-1}$ in Rhode River waters compared to a model range of ca 1000 to $15000 \mathrm{ml}^{-1}$. Bacterioplankton concentrations varied from ca 0.4 to $4 \times 10^{6} \mathrm{ml}^{-1}$ and 0.6 to $3 \times$ $10^{6} \mathrm{ml}^{-1}$ in field samples and in the simulation, respectively The model correctly predicted the qualitative observation that peak concentrations of bacterioplankton corresponded with peak concentrations of rotifers as was seen in both the field data and tank experiments. The natural populations oscillated with irregu-
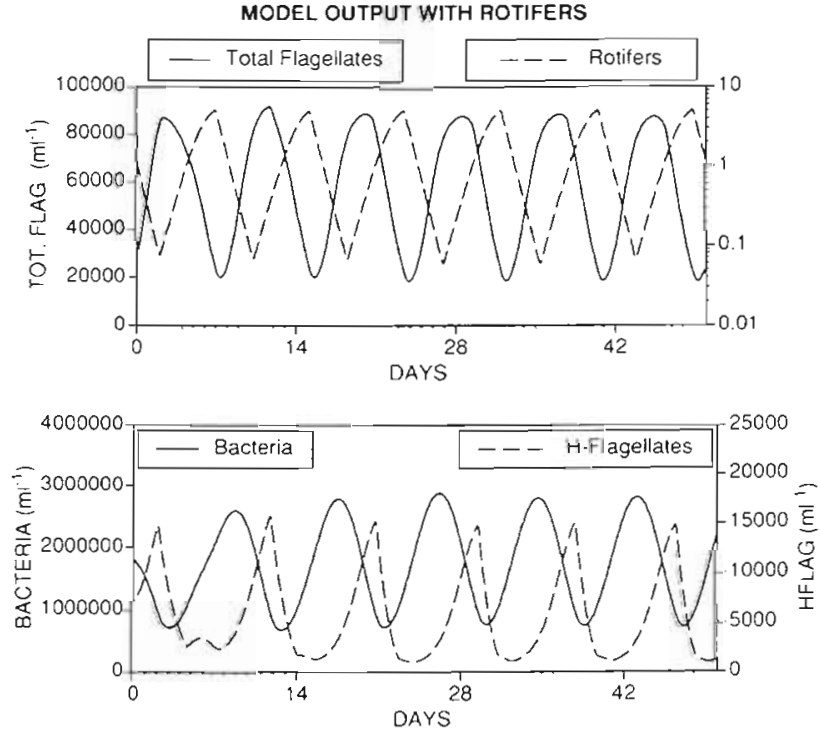

Fig. 7 Temporal changes in total microflagellate, rotifer, bacteria, and heterotrophic microflagellate abundances generated by the computer simulation of the model food web (see 'Discussion' for details)

lar periods of 4 to $8 \mathrm{~d}$ while the model yielded a regular period of $8.3 \mathrm{~d}$.

We used the model to investigate the effects of rotifers on the heterotrophic microflagellate relationship. Removal of rotifers in the model resulted in a more closely coupled predator-prey relationship between bacteria and flagellates; that is, both the period and 

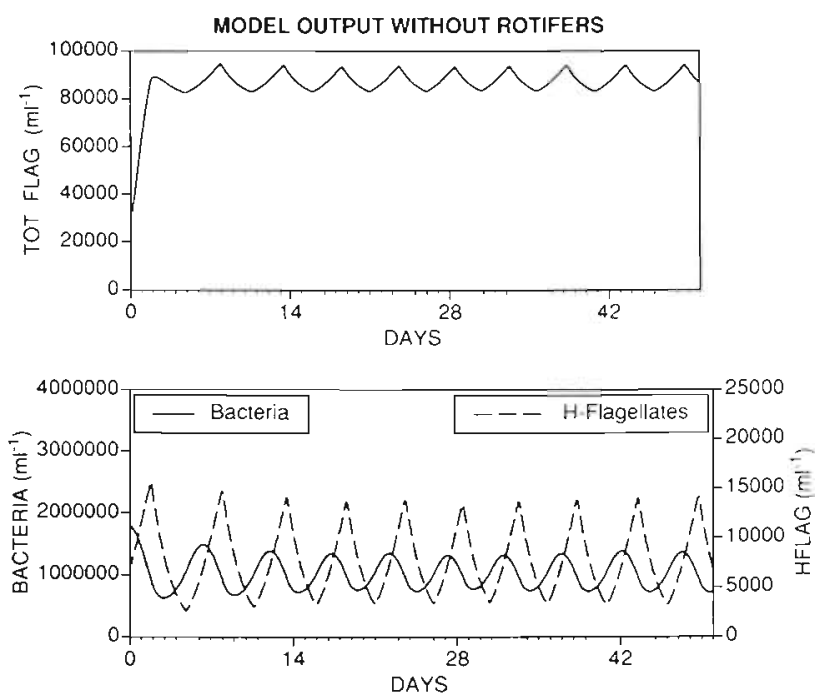

Fig. 8. Temporal changes in total microflagellate, heterotrophic microflagellate and bacterial abundances generated by simulation of a model food web without rotifers

amplitude of oscillations as well as the average concentration of bacteria were reduced (Fig. 8). Such differences in the heterotrophic microflagellate-rotifer patterns in the tank experiment might have been apparent had the experiment been continued for a second week. Alternatively, the patterns in the field and tank experiments, which were clearly much less straightforward than those seen in the model, may represent the influence of mixotrophic microflagellates and flagellateconsuming ciliates.

Sensitivity analysis of the model indicated that, not surprisingly, periods varied with the magnitude of growth and death rates and that the system was numerically unstable or one of the groups crashed if flagellate or bacterial carrying capacities were removed. An interesting finding was that the periods and amplitudes of all the groups were very sensitive to changes in the time lag between flagellate abundance and rotifer growth; they increased markedly with the time lag.

\section{CONCLUSION}

Data presented here indicate that in the Rhode River, rotifer predation probably periodically reduced heterotrophic microflagellate stocks and thereby reduced grazing pressure on bacterioplankton. Thus far, studies of metazoan predation on protozoa have focused on the importance of protists in metazoan diets and while protozoa probably constitute an important or essential nutrient resource for many metazoan zooplankton (Stoecker \& Capuzzo 1990), investigations of protozoan-metazoan interactions which focus on the value of the protist to the metazoan may miss some important interactions. In the Rhode River, regardless of their importance as a dietary resource or carbon link to higher trophic levels, microbial loop populations can be profoundly influenced by metazoans and the effects can appear in a lower trophic level.

Acknowledgements. This research was supported by the Office of Fellowships and Grants of the Smithsonian

\section{LITERATURE CITED}

Azam, F., Fenchel, T., Field, J. G., Gray, J. S., Meyer-Reil, L. A., Thingstad, F. (1983). The ecological role of watercolumn microbes in the sea. Mar. Ecol. Prog. Ser. 10: $257-263$

Borsheim, K. Y., Bratbak, G., Heldal, M. 1990. Enumeration and biomass estimation of planctonic bacteria and viruses by transmitted electron microscopy. Appl. environ. Microbiol. 56: 352-356

Brownlee, D. C., Jacobs, F. (1987). Mesozooplankton and microzooplankton in the Chesapeake Bay. In: Majumadar, S. K., Hall, L. W., Austin, H. M. (eds.) Contaminant problems and management of living Chesapeake Bay resources. Phil. Acad. Sci., Philadelphia, p. 217-269

Cory, R. L., Dresler, P. V (1981). Diel oxygen variations in the Rhode River estuary, Maryland 1970-1978. U.S.G.S. Wat. Res. Inves. 81-10

Cushing, D. H. (1976). Grazing in Lake Erken. Limnol. Oceanogr 21:349-356

Capriulo, G. M., Sherr, E. B., Sherr, B. F. (1991). Trophic behaviour and related community feeding activities of heterotrophic marine protists. In: Ried, P. C., Turley, C. M., Burkill, P. H. (eds.) Protozoa and their role in marine processes. Springer-Verlag, Berlin, p. 219-279

Chrzanowski, T. H., Simek, K. (1990). Prey-size selection by freshwater flagellated protozoa. Limnol. Oceanogr. 35: $1429-1436$

Coffin, R. B., Sharp, J. K. (1987). Microbial trophodynamics in the Delaware Estuary. Mar. Ecol. Prog. Ser. 41: 253-266

Davis, P. G., Caron, D. A., Johnson, P. W., Sieburth, J. McN. (1985). Phototrophic and apochloritic components of picoplankton and nanoplankton in the North Atlantic: geographic, vertical, seasonal and diel distributions. Mar. Ecol. Prog. Ser. 21: 15-26

Dolan, J. R., Coats, D. W (1990). Seasonal abundances of planktonic ciliates and microflagellates in mesohaline Chesapeake Bay waters. Estuar coast. Shelf Sci. 31: $157-175$

Ducklow, H. W., Purdie, D. A., Williams, P. Leb., Davis, J. M. (1986). Bacterioplankton: a sink for carbon in a coastal marine plankton community. Science 232: 865-867

Egloff, D A. (1988). Food and growth relations of the marine microzooplankter, Synchaeta cecilia (Rotifera). Hydrobiologia 157: 129-141

Elser, J. J., Carpenter, S. R. (1988). Predation-driven dynamics of zooplankton and phytoplankton communities in a whole lake experiment. Oecologia 76: 148-154

Fenchel, T (1986). Ecology of heterotrophic microflagellates. Adv. microbiol. Ecol. 9: 57-97

Frost, B. W (1972). Effects of size and concentration of food particles of the feeding behavior of the marine planktonic copepod Calanus pacificus. Limnol. Oceanogr. 17 : 805-815

Gallegos, C. L. (1989). Microzooplankton grazing on phyto- 
plankton in the Rhode River, Maryland: nonlinear feeding kinetics. Mar Ecol. Prog. Ser 57: 23-33

Gilbert, J. J., Bogdan, K. G. (1984). Rotifer grazing: in situ studies on selectivity and rates. In: Meyers, D. G., Strickler, J. R. (eds.) Trophic interactions within aquatic ecosystems. Am. Ass. Advmt. Sci., Washington, D.C., p. 97-133

Gonzalez, J. M., Sherr, E. B., Sherr, B. F. (1990). Size-selective grazing on bacteria by natural assemblages of estuarine flagellates and ciliates. Appl. environ. Microbiol. 56: 583-589

Grover. J. P. (1990). Grazing by a heterotrophic microflagellate on two diatoms: functional and numerical responses in laboratory cultures. Arch. Hydrobiol. 119: 197-214

Hass, L. W. (1982). Improved epifluorescent microscopic technique for observing planktonic micro-organisms. Annls. Inst. océanogr., Paris 58: 285-295

Heinbokel, J. F. (1978). Studies on the functional role of tintinnids in the Southern California Bight. I. grazing and growth rates in laboratory cultures. Mar. Biol. 47: 177-189

Heinbokel, J. F., Coats, D. W., Henderson, K. W., Tyler, M. A (1988). Reproduction rates and secondary production of three species of the rotifer genus Synchaeta in the estuarine Potomac River. J. Plankton Res. 10: 659-674

Hines, A. H., Haddon, P. J., Miklas, J. J., Wiechert, L. A., Haddon, A. M. (1987). Estuarine invertebrates and fish: sampling design and constraints for long-term measurements of population dynamics. In: Boyce, T. D. (ed.) New approaches to monitoring aquatic ecosystems. American Society for Testing and Materials, ASTM STP 940, p. $140-164$

Hopkinson, C. S., Sherr, B., Weibe, W. J. (1989). Size fractionated metabolism of coastal microbial plankton. Mar. Ecol. Prog. Ser. 51. 155-166

Kerfoot, W. C. (1987). Cascading effects and indirect pathways. In: Kerfoot, W. C., Sih, A. (eds.) Predation: direct and indirect impacts on aquatic communities. University Press of New England, Hanover, New Hampshire, p. 57-70

Kuuppo-Leinikki, P. (1990). Protozoan grazing on planktonic bacteria and its impact on bacterial population. Mar Ecol. Prog. Ser 63: 227-238

Malone, T. C., Ducklow, H. W. (1990). Microbial biomass in the coastal plume of Chesapeake Bay: phytoplankton-bacterioplankton relationships. Limnol. Oceanogr 35: 296-312

This article was presented by B. and E. Sherr, Corvallis, Oregon, USA
McQueen, D. J., Johannes, M. R. S., Post, J. R., Stewart, T J. (1989). Bottom-up and top-down impacts on freshwater pelagic community structure. Ecol. Monogr. 59: 289-309

Miller, T E., Kerfoot, W. C. (1987). Redefining indirect effects. In: Kerfoot, W C., Sih, A. (eds.) Predation: direct and indirect impacts on aquatic communities, University Press of New England, Hanover, New Hampshire, p. 33-37

Porter, K. G., Feig. Y. S. (1980). The use of DAPI for identifying and counting aquatic microflora. Limnol. Oceanogr. 25 943-948

Pourriot, R. (1977). Food and feeding habits of rotifera. Arch Hydrobiol. (Beih. Ergebn. Limnol.) 8: 243-260

Rublee, P. A., Merkel, S. M., Faust, M. A., Miklas, J. (1984) Distribution and activity of bacteria in the headwaters of the Rhode River estuary, Maryland, U.S.A. Microb. Ecol 10: $243-255$

Sanders, R. W (1991). Mixotrophic protists in marine and freshwater ecosystems. J. Protozool. 38: 76-81

Sellner, K. G., Brownlee, D. C., Harding, L. W. Jr (1987) Implications of microzooplankton grazing on carbon flux and anoxia in the Chesapeake Bay. In: Mackierman, G. B. (ed.) Dissolved oxygen in the Chesapeake Bay (University of Maryland Sea Grant Publ. UM-TS-87-03). University of Maryland Sea Grant, College Park, Maryland

Sherr, E. B., Sherr, B. F., Albright, A. J. (1987a). Bacteria: sink or link? Science 235: 88-89

Sherr, B. F., Sherr, E. B., Pedros-Alio, C. (1989). Simultaneous measurement of bacterioplankton production and protozoan bacteriovory in estuarine water. Mar. Ecol. Prog. Ser. 54: 209-219

Sherr, E. B., Sherr, B. F., McDaniel, J. (1991). Clearance rates of $<6 \mu \mathrm{m}$ fluorescently labeled algae (FLA) by estuarine protozoa: potential grazing impact of flagellates and ciliates. Mar. Ecol. Prog. Ser. 69: 81-92

Stemberger, R. S., Gilbert, J. J. (1985). Body size, food concentration, and population growth in planktonic rotifers. Ecology 66: 1151-1159

Stemberger, R. S., Gilbert, J. J. (1987). Rotifer threshold food concentrations and the size-efficiency hypothesis. Ecology 68: $181-187$

Stoecker, D. K., Capuzzo, J. M. (1990). Predation on protozoa: its importance to zooplankton. J. Plankton Res. 12: $891-908$

Manuscript first received: March 11, 1991

Revised version accepted: August 26, 1991 